\title{
Regulation of Wolffian Duct Development
}

\author{
Sabine E. Hannema leuan A. Hughes \\ Department of Paediatrics, Addenbrooke's Hospital, University of Cambridge, Cambridge, UK
}

\section{Key Words}

Wolffian duct $\cdot$ Testosterone $\cdot$ Growth factors · Epididymis ·

Vas deferens $\cdot$ Sexual development

\begin{abstract}
Wolffian ducts (WDs) are the embryonic structures that form the male internal genitalia. These ducts develop in both the male and female embryo. However, in the female they subsequently regress, whereas in the male they are stabilised by testosterone. The WDs then develop into separate but contiguous organs, the epididymis, vas deferens and seminal vesicles. Recently, considerable progress has been made in identifying genes that are involved in these different stages of development which is described in this review. In addition, WD development in (atypical forms of) cystic fibrosis and intersex disorders, such as the complete androgen insensitivity syndrome, 17 $\beta$-hydroxysteroid dehydrogenase deficiency and LH-receptor defects, is discussed. The apparent increase in male reproductive tract disorders is briefly discussed from the perspective of the potential endocrinedisrupting effects of the numerous chemicals in the environment to which the developing male foetus can be exposed. Copyright ๑ 2007 S. Karger AG, Basel
\end{abstract}

This work was supported by the Birth Defects Foundation. S.E. Hannema is a recipient of a 2001 Nuffic Talents Award (Dutch Ministry of Education) and a Gates Cambridge Scholarship.

\section{KARGER}

Fax +41613061234 E-Mail karger@karger.ch www.karger.com
(ㄷ) 2007 S. Karger AG, Basel

0301-0163/07/0673-0142\$23.50/0

Accessible online at:

www.karger.com/hre

\section{Introduction}

Wolffian ducts (WDs) are the embryonic structures that form the male internal genitalia. Their development is therefore essential to male fertility. In addition, the WD plays a crucial role in kidney development, both in the male and female embryo, as well as in development of the Müllerian duct (MD). The MD is the precursor of the female reproductive tract which has been subject of a previous review [1]. In recent years, considerable progress has been made in elucidating the genes involved in regulation of WD development, as summarised in the present review. Also discussed is the pathophysiology of WD development in cystic fibrosis and intersex disorders, together with reference to the potential effects of endocrine disrupters on WD development. Medline was searched using the terms 'Wolffian duct', 'epididymis' and 'vas deferens' and the MESH term 'mesonephric duct' to identify articles on these subjects; references from articles found in the original search were also used.

\section{Embryology of the Mesonephric Tubules and Wolffian Ducts}

Two pairs of unipotential ducts, the WDs (also known as mesonephric ducts) and MDs (also known as paramesonephric ducts) are anlagen of the male and female reproductive tracts respectively, and form independent of the genetic sex of the embryo. The WD forms from the intermediate mesoderm at E9 in mice, in craniocaudal succession. It initially forms as an extension of the pronephric duct in the region of the future forelimb buds,

S.E. Hannema

Department of Paediatrics, Juliana Children's Hospital

Sportlaan 600

NL-2566 MJ The Hague (The Netherlands)

Tel. +31 70312 7000,Fax +31 70312 6160,E-Mail sehannema@cantab.net 
Fig. 1. Schematic drawing of the development of the male genital tract in humans. a Schematic drawing showing the excretory system of the gonad and MES at 8 weeks gestation. SEM anastomose to form the RT, which is connected to the MT that drain into the WD. Mesonephric tubules that are not connected to the testis degenerate. b Male urogenital tract in a newborn. The mesonephric tubules and WDs have developed into ED, EPID, VAS and $\mathrm{SV} . \mathrm{BL}=$ Bladder; $\mathrm{ED}=$ efferent ducts; EPID = epididymis; $M D=$ Müllerian duct; MES = mesonephros; MT = mesonephric tubules; RT = rete testis; $\mathrm{SEM}=$ seminiferous cords; $\mathrm{SV}=$ seminal vesicle; $\mathrm{UR}=$ urethra; VAS = vas deferens; WD $=$ Wolffian duct.

Fig. 2. Development of the foetal rat WD. Macroscopic photos of the WD at E18.5 (a), E19.5 (b) and E20.5 (c) showing growth and coiling of the duct. Scale bars $=1 \mathrm{~mm}$.
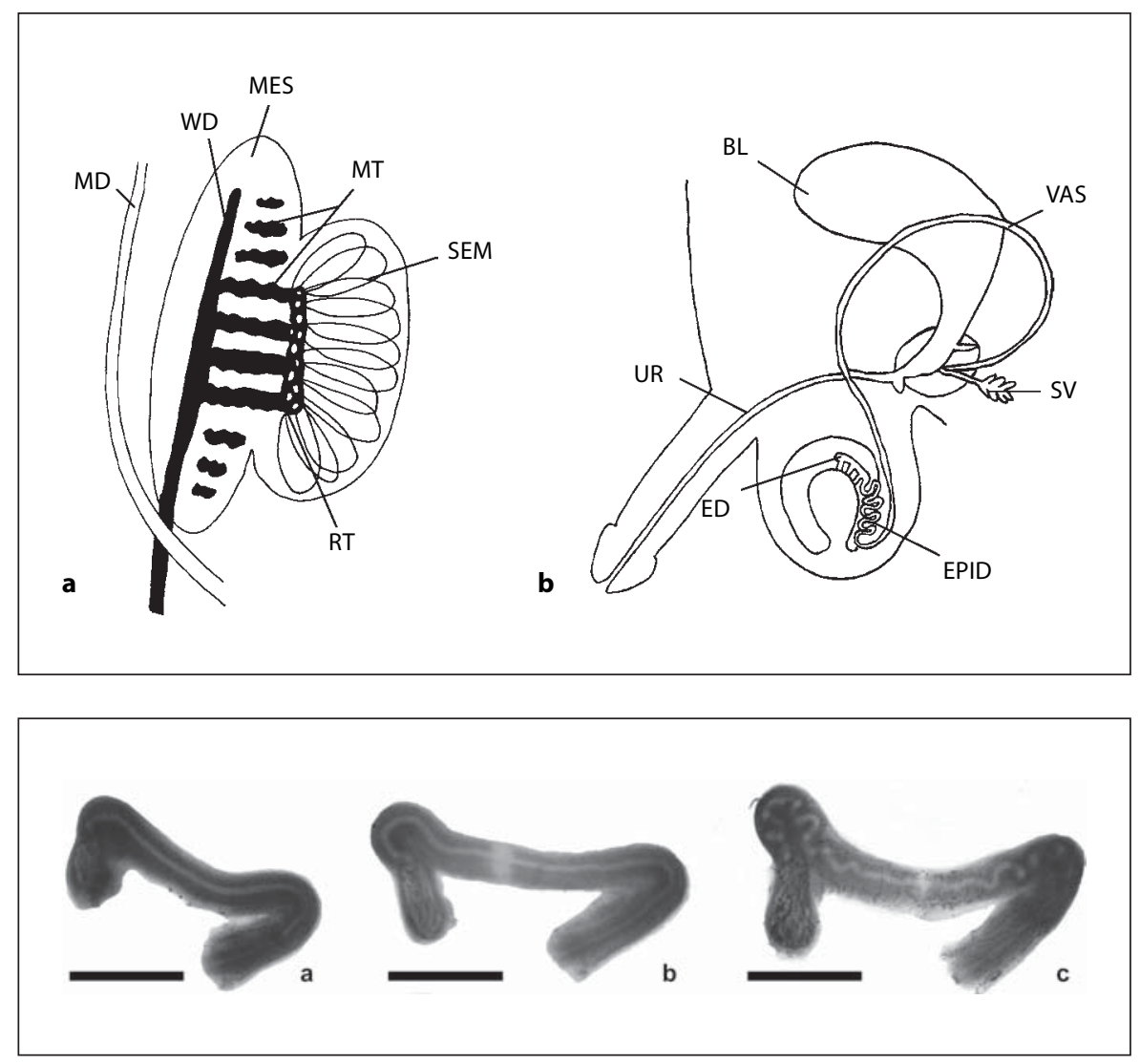

and grows caudally to the cloaca. The WD induces the formation of mesonephric tubules in the mesonephric mesenchyme, which extend to the epithelial cells of the gonad in both males and females [2] (fig. 1a). In rodents, the four to six most cranial tubules bud from the WD, whereas the more caudal tubules are close to, but not connected to the WD [3]. The caudal tubules degenerate in males and females, but the cranial tubules persist in males to form the efferent ducts [3]. The ureteric bud branches from the WD posteriorly, to form the kidney through interaction with the metanephric mesenchyme.

The WD differentiates between weeks 9 and 13 of gestation in the human male embryo. The proximal part coils and forms the epididymis, whereas the distal part forms the vas deferens (figs. 1b, 2). The seminal vesicles develop from lateral outgrowths of the caudal end of the vas deferens. In females, the mesonephric tubules and WDs degenerate, although remnants may be present in the form of an appendix vesiculosa, epoophoron, paroophoron or duct of Gartner.

The MD forms in an anterior to posterior manner by invagination of the coelomic epithelium of the meso- nephros, between E11.5 and E12.5 in mice [2], and between 6 and 7 weeks of gestation in humans [4]. The presence of the WD appears to be essential to induction of MD formation. When caudal outgrowth of the WD is blocked before it has reached the area of coelomic epithelium from which the MD normally forms, the MD fails to develop [5].

\section{Genes Involved in Early Formation of the Wolffian Ducts}

The use of mouse knockout models has provided much insight into genes involved in the development of WD. However, it has to be kept in mind that for many of these genes the relevance to WD development in humans still needs to be investigated.

Several genes are involved in the initial development of the WD and MD, which is similar in males and females (fig. 3). Pax2, a transcriptional regulator of the paired-box family is expressed in the epithelium of the mesonephric tubules as well as the WD and MD. Pax2-deficient mice 
lack kidneys and genital ducts, but the gonads develop normally [6]. The anterior portion of the genital ducts forms but subsequently degenerates, whereas mesonephric tubules never develop [6]. Pax8 is coexpressed with Pax2 and has redundant functions in urogenital development [7]. Disruption of Pax8 does not result in urogenital abnormalities, but in mice lacking both Pax2 and Pax8, the WD fails to develop, and cells that normally express Pax2 undergo apoptosis [7]. These findings suggest that Pax 2 and Pax 8 proteins are required for mesenchymalepithelial conversion, a process which is essential for the formation of WD and mesonephric tubules [6,7].

Lim1, which encodes a homeodomain transcription factor, is also expressed in epithelium of the mesonephric tubules, WD and MD [8]. Mice that lack this gene, do not have WD and MD derivatives. Lim1 may play a role in the formation or very early differentiation of MD and WD epithelium [8] and may act as a co-factor co-operating with Pax2 and Pax8 [7].Emx2 is also required for the formation of both pairs of genital ducts. It is expressed in the epithelium of the WD at E9.5, epithelium of the mesonephric tubules at E10.5, and the epithelium of the MD at E12.5 [9]. In Emx2 null mice, the WD and mesonephric tubules appear normal at E10.5, but the WD has started to degenerate by E11.5 and no MDs are present at E13 [9]. Retinoic acid signalling also plays a role in WD and MD development. Compound null mutations of retinoic acid receptors $\alpha$ and $\gamma$, or subtypes of these receptors, are associated with agenesis or dysplasia of the epididymis, vas deferens and seminal vesicles [10]. Mutations of these and other (sub)types of retinoic acid receptors also result in abnormalities of the MD [10].

Results from studies of Wt1 null mice show that Wt1 is required for the formation of caudal mesonephric tubules, but not the cranial tubules that later form the efferent ducts [3]. The caudal tubules are thought to derive from the mesonephric mesenchyme, but the cranial tubules may (partly) derive from the WD and development of these tubules may be androgen-dependent [3].

\section{Differentiation of Sections of the Wolffian Duct}

Region specific expression of several homeobox genes is important for differentiation of the WD into morphologically and functionally distinct structures: the epididymis, vas deferens and seminal vesicle. The Drosophila Abdominal B-related homeobox genes appear to be involved in defining tissue boundaries between these structures in mice. In the male mouse, Hoxa9 and Hoxd9 are expressed in the epididymis and vas deferens, Hoxa10 and Hoxd10 mainly in the caudal epididymis and throughout the vas deferens, Hoxal1 in the vas deferens, and Hoxal3 and Hoxd13 in the caudal portion of the WD and seminal vesicles [11-15]. Studies on cultures of the urogenital sinus suggest Hoxa10 expression is not regulated by androgens [13].

Mutations in Hoxa10 result in anterior homeotic transformation of the WD [16]; the distal epididymis and proximal vas deferens show morphological characteristics of more anterior segments. Disruption of Hoxal1 also results in a homeotic transformation of the vas deferens towards an epididymis-like phenotype [11]. Disruption of Hoxd13 alone leads to reduced size and reduced clefting of the seminal vesicles, whereas Hoxa $13^{+/-} /$Hoxd $13^{-/-}$ mice display a more severe phenotype, with severely hypoplastic seminal vesicles [15].

\section{Genes Involved in Androgen-Dependent Development of the Wolffian Duct}

\section{Androgens and the Androgen Receptor}

The WD once formed, will regress unless it is actively stimulated to grow. Testosterone is thought to be the sole factor responsible for stabilisation of the WD [17]. Leydig cells start producing testosterone at 8 weeks of gestation in humans, and at E15.5-E16.5 in rats [18]. Testosterone is thought to be secreted directly into and down the WD by diffusion [19]. Jost [17] demonstrated that castration of male rabbit foetuses before sexual differentiation has begun, results in regression of the WDs. However, a crystal of synthetic androgen placed in the abdominal cavity of castrated foetuses, whether male or female, prevents WD regression. Unilateral castration only results in atrophy of the WD on the operated side, suggesting the effect of a high local concentration of androgen. Testosterone interacts with the androgen receptor (AR) to exert its effects. Mice lacking $A R$ show agenesis of the epididymis, vas deferens and seminal vesicles [20].

During WD development, $A R$ expression itself is regulated by androgens [21]. The male pattern of $A R$ expression is seen in the WD of female rat foetuses exposed to dihydrotestosterone (which results in WD stabilisation), and at E21 the $A R$ is not expressed in the WD mesenchyme of male foetuses exposed to the anti-androgen flutamide [21]. In the normal male rat foetus, $A R$ is first expressed in the mesenchymal cells and subsequently in the epithelial cells [21]. This induction progresses in a proximal to distal manner. 
Fig. 3. Genes involved in WD development. Overview of genes implicated in early formation of the WD (occurring in both sexes), androgen-dependent stabilisation of the WD and differentiation of the WD into distinct subsections. RAR = Retinoic acid receptor.

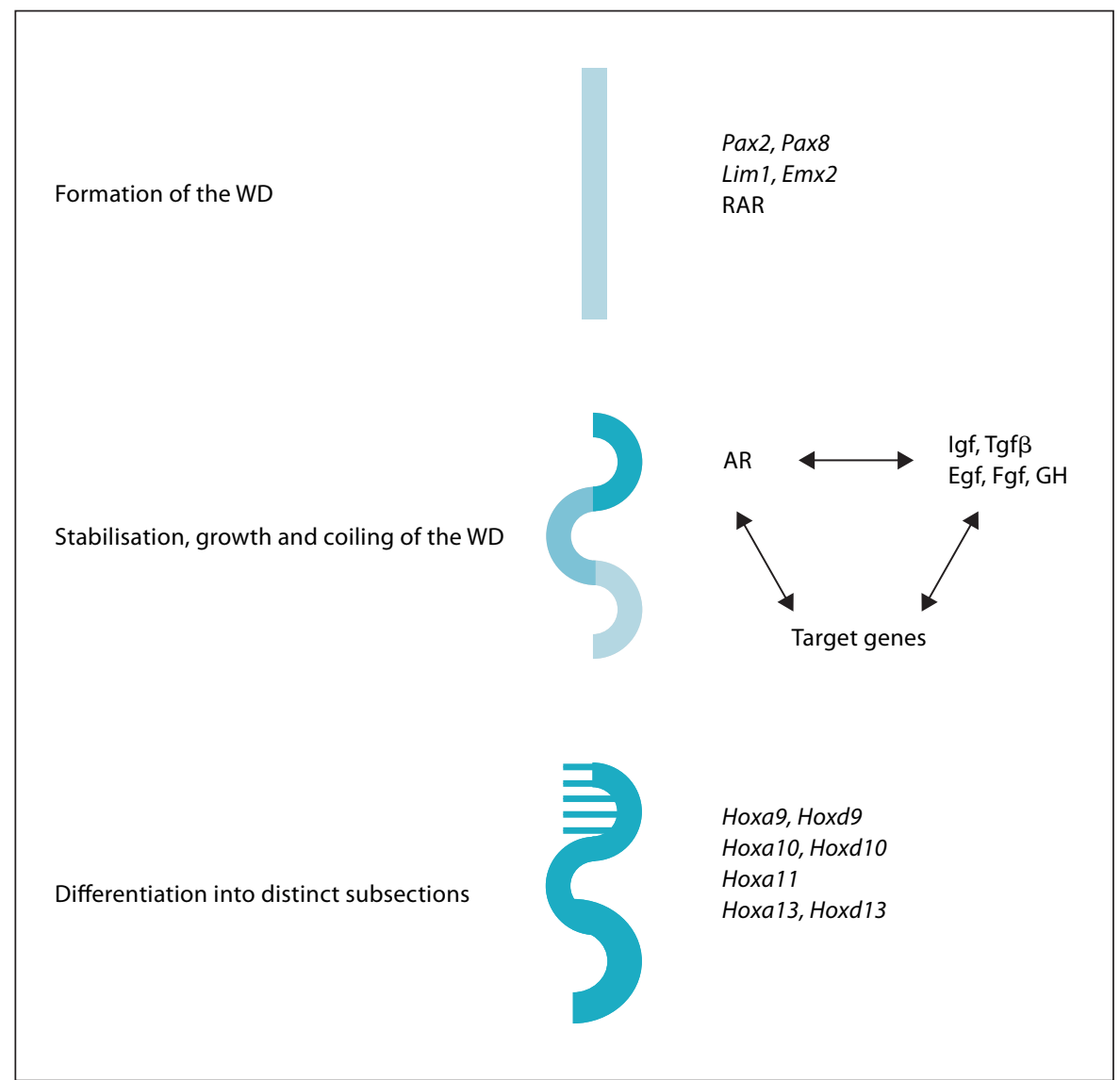

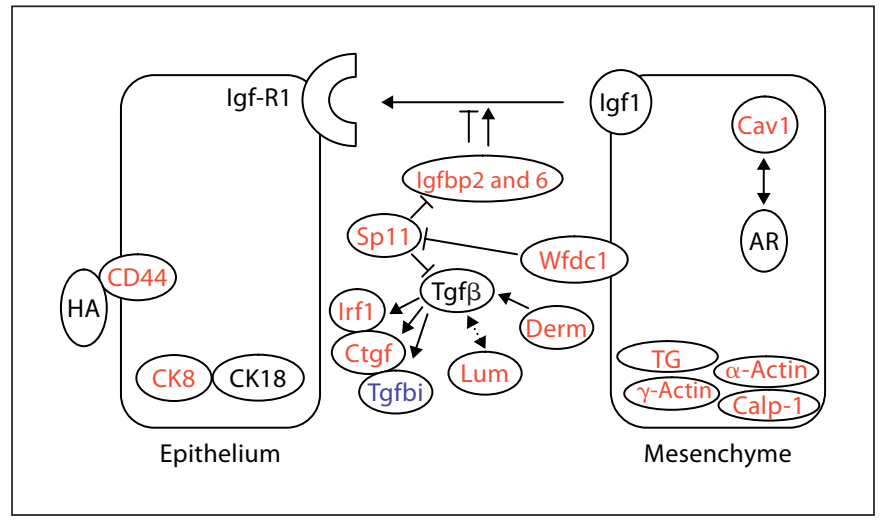

Fig. 4. Model of the interaction of several genes in the developing $\mathrm{WD}$, previously shown to be upregulated (red) and downregulated (blue) between E17.5 and E20.5 [39]. Calp1 = Calponin-1; Cav1 = caveolin -1 ; CK8 = cytokeratin -8 ; Ctgf = connective tissue growth factor; Derm = dermatopontin; HA = hyaluronan; Irf1 = interferon regulatory factor-1; Lum = lumican; Sp11 = serine protease $11 ; \mathrm{TG}=$ transgelin; Tgfbi $=$ Tgf $\beta$-induced; Wfdc1 = WAP four disulfide core domain-1.

Regulation of Wolffian Duct Development

\section{Epithelial-Mesenchymal Interactions}

The fact that the AR appears in the mesenchyme before it is expressed in the epithelium, suggests that androgens initially induce their effects on the epithelium via signals from the mesenchyme. This idea is supported by studies showing that, in tissue recombinants, seminal vesicle mesenchyme can induce proliferation and differentiation of AR negative epithelium from androgen insensitive $t f m$ mice [22]. However, epithelial $A R$ expression is a prerequisite for some functions, such as the synthesis of secretory proteins [22]. Epithelial $A R$ expression is thought to be induced by the mesenchyme [23].

Interactions between epithelium and mesenchyme are essential for the development of many organs, including the WD. The mesenchyme determines the fate of the epithelium. Experiments using tissue recombinants have shown that epithelium from both the ureter and the upper WD, which normally develops into the epididymis, can be redirected to develop morphological and functional characteristics of seminal vesicle epithelium when recombined with seminal vesicle mesenchyme $[24,25]$.

Horm Res 2007;67:142-151 
Conversely, growth of the mesenchyme is dependent on signals from the epithelium, as was demonstrated by failure of grafts of seminal vesicle mesenchyme alone to develop $[24,25]$. The AR presumably plays a role in the regulation of factors that mediate or affect epithelialmesenchymal interactions. Growth factors appear to be examples of such mediators.

\section{Growth Factors}

Epidermal growth factor ( $E g f)$ expression in the mouse WD appears to be regulated by androgens [26]. Egf mRNA levels increase during WD development in the male foetus and are higher in the male than in the female reproductive tract at E18. The levels can be increased in the female reproductive tract by treatment with testosterone (which also results in WD stabilisation) and reduced in the male reproductive tract by treatment with antiandrogens (which inhibit WD development) [26]. Similarly, Egf receptor is present at higher levels in the male than in the female reproductive tract at E18, and expression in females is increased after testosterone treatment [27]. Moreover, Egf in the absence of the testis, can maintain WD in culture and anti-Egf and anti-Egf receptor antibodies can prevent WD development in the presence of a testis $[28,27]$. Interestingly, WD stabilisation by Egf can be blocked by anti-androgens, suggesting that the AR mediates Egf-induced effects [29]. This is supported by the finding that Egf can modulate AR activity in mesenchymal cells of the mouse foetal reproductive tract [30].

Growth hormone $(\mathrm{GH})$ has also been found in the foetal mouse male reproductive tract, and can stabilise the WD in culture [31]. Anti-GH antibody prevents WD stabilisation by the testis or testosterone in vitro. This effect can be reversed by supplementation with GH or, more effectively, with insulin-like growth factor 1 (Igf1), suggesting the effects of GH in the WD may be mediated by Igf1 [31].

Igf has been detected in prepubertal mice in the myofibroblastic cells surrounding the epididymis and the type 1 Igf receptor is expressed in the epithelium [32]. An important role for Igf in WD development is further supported by the observation that Igf1 null mice have severe reproductive abnormalities [32]. They have a disproportionately small corpus and cauda epididymis, vas deferens and seminal vesicles and the cauda epididymis lacks the numerous ductal convolutions that are characteristic of this region [32]. These changes may be due partly to decreased testosterone levels in Igf1 null mice.

Transgenic mice that ectopically express fibroblast growth factor 3 ( Fgf3) in the WD and prostate, have ex- tremely enlarged reproductive tracts; in mice older than 4 months, WD derivatives weigh as much as $10 \%$ of total body weight [33]. The epididymides and vasa deferentia of these animals show epithelial stratification and contain haemorrhagic cysts. The physiological role of Fgf3 in the WD is not clear, but Fgf10 has been detected in the normal epididymis and is important for the development of seminal vesicles [34]. Similarly, Fgf7 is expressed in the developing mouse seminal vesicle in vivo and is thought to partially mediate androgen-induced growth [35].

Transforming growth factor $\beta(\operatorname{Tgf} \beta)$ may also play a role in WD development. Tgf $\beta 2$ knockout mice have urogenital defects. Males examined by Sanford et al. [36] had ectopic testes and one mouse had unilateral testicular hypoplasia with lack of an epididymis and dysgenesis of the vas deferens. Tgf $\beta$ receptor type 3 null mice, which show decreased sensitivity to $\operatorname{Tgf} \beta 2$, are subfertile when they survive until after birth, although it is unclear what is the direct cause of reduced fertility [37].

AR may directly regulate expression of the growth factors discussed above, but may also indirectly regulate growth factor activity through other molecules. Connective tissue growth factor, e.g., which increases activity of Fgfs [38], and Igf-binding proteins 2 and 6, which affect Igf activity, are upregulated during WD development in the rat [39] (fig. 4). Similarly, expression of proteins known to potentiate $\mathrm{Tgf} \beta$ activity, such as dermatopontin [40], increases in the developing rat WD [39].

The mouse efferent ducts and epididymis undergo extensive remodelling during the first days after birth. The postnatal process of elongation and convolution is disturbed in mice lacking the leucine-rich $G$ protein-coupled receptor 4 , resulting in severely hypoplastic and dilated efferent ducts and epididymis with an abnormal cell arrangement [41]. Leurine-rich $\mathrm{G}$ protein-coupled receptor appears to regulate proliferation of the epithelium and mesenchyme, and might also play a role in epithelialmesenchymal interactions [41].

Taken together, several proteins have been identified that may be important in WD development. However, their precise role, the mechanism of their interaction and how they are regulated by androgens, remain unknown.

\section{Disorders of WD Development}

Congenital Bilateral Absence of the Vas Deferens

Disorders of WD development are relatively common. Congenital bilateral absence of the vas deferens is estimated to occur in $1: 1,000$ to $1: 10,000$, responsible for $1-$ 
$2 \%$ of cases with male infertility and for $9.6 \%$ of cases with obstructive azoospermia $[42,43]$. It is thought to result from abnormal development of the WDs, although it is not entirely certain that absence of the vas deferens is always congenital [43]. Approximately $80 \%$ of cases is caused by mutations on both alleles of the cystic fibrosis transmembrane conductance regulator (CFTR) gene [42]. In patients with relatively mild mutations absence of the vasa deferentia may be the only manifestation of cystic fibrosis [42]. Congenital bilateral absence of the vas deferens is characterised by absence of the body and tail of the epididymis as well as the vas deferens and seminal vesicles, but the head of the epididymis is consistently present. The head seems to function normally, since sperm harvested from it has been used to establish successful pregnancies through intracytoplasmic sperm injection [44]. Absence of the more distal WD derivatives appears to be due to early obstruction of the ducts by dehydrated secretions, rather than a true developmental defect. CFTR is expressed at high levels in the head of the epididymis, which has a predominantly secretory function. Lower and more variable levels of CFTR are present in the distal epididymis, which has a reabsorptive role [45]. Dysfunction of the CFTR in the head of the epididymis is likely to make more distal parts of the male genital tract, which have a higher protein load, prone to flow obstruction. Interestingly, the phenotype of the CFTR knockout mouse is much less severe [46]. The vas deferens is present, but the lumen is small up to day 44 and filled with secretions. The appearance of spermatozoa in the lumen is delayed, and although spermatozoa do appear, two out of three knockout mice were infertile.

\section{Complete Androgen Insensitivity Syndrome}

Abnormal WD development may also occur in patients with various disorders of sex development. Studies of $A R$ knockout mice [20] have confirmed the central role of the AR in reproductive development. These mice have female external genitalia and do not have WD derivatives. Severe AR mutations in humans result in the complete androgen insensitivity syndrome, also characterised by female external genitalia [47, 48 and www. androgendb.mcgill.ca]. However, WD derivatives have been found in some of these patients [47, 49-51]. These were initially thought to be remnants that had failed to completely regress $[47,49,50]$, but recent work has shown that well-developed epididymides/vasa deferentia are present in approximately $40 \%$ of patients [51, 52] (fig. 5). Such patients harbour mutant receptors that show residual response to high concentrations of androgens when studied in an in vitro functional assay. Correspondingly, the mutant AR may respond to the high local concentration of testosterone in the WD in vivo, whereas there is insufficient ligand induction of the mutant AR in the external genitalia from lower circulating concentrations of androgen [51].

\section{$17 \beta$-Hydroxysteroid Dehydrogenase Deficiency}

The difference between the local concentration of androgen in the WD and that in the systemic circulation may also be a part explanation for WD development in other disorders of sex development. The conversion of androstenedione to testosterone is impaired in $17 \beta$-hydroxysteroid dehydrogenase deficiency. Affected individuals usually have female external genitalia at birth, although clitoromegaly may be present, but have normally developed epididymides and vasa deferentia [53]. Measurements of testosterone levels in the spermatic vein of two adult patients showed a concentration ranging from 35 to $180 \mathrm{nM}$, levels 15-70-fold lower than those found in normal men [53]. However, this may still be sufficient for WD stabilisation. Since androstenedione levels were increased 15-20-fold (up to $1.5 \mu \mathrm{M}$ ), this could contribute to ligand-activation of the AR and WD development. Androstenedione is capable of inducing AR transcriptional activity, even though the AR binds androstenedione with a lower affinity than testosterone [54].

\section{LH Receptor Mutations}

Inactivating mutations of the LH receptor lead to Leydig cell hypoplasia in affected males, which results in a spectrum of disorders of sex development, ranging from complete XY sex reversal to isolated hypospadias or micropenis $[55,56]$. Even when the external genitalia are female, the epididymides and vasa deferentia are present despite low concentrations of testosterone in the spermatic vein. Interestingly, $\mathrm{LH}$ receptor gene knockout male mice are not completely sex-reversed but have micropenis and small abdominal testes [57]. The epididymis and vas are present, albeit underdeveloped. The mice have a dramatic decrease in serum testosterone levels with a concomitant marked increase in LH levels. Testosterone replacement in 30-day homozygous knockout males, using pellets to provide a continuous concentration gradient diffusion system, stimulated epididymal growth to that comparable with wild-type litter mates [58]. While these observations confirm the predominance of androgen-dependent WD stabilisation, the presence of some epididymal and vas development in humans with LH receptor mutations and in LH receptor knockout 


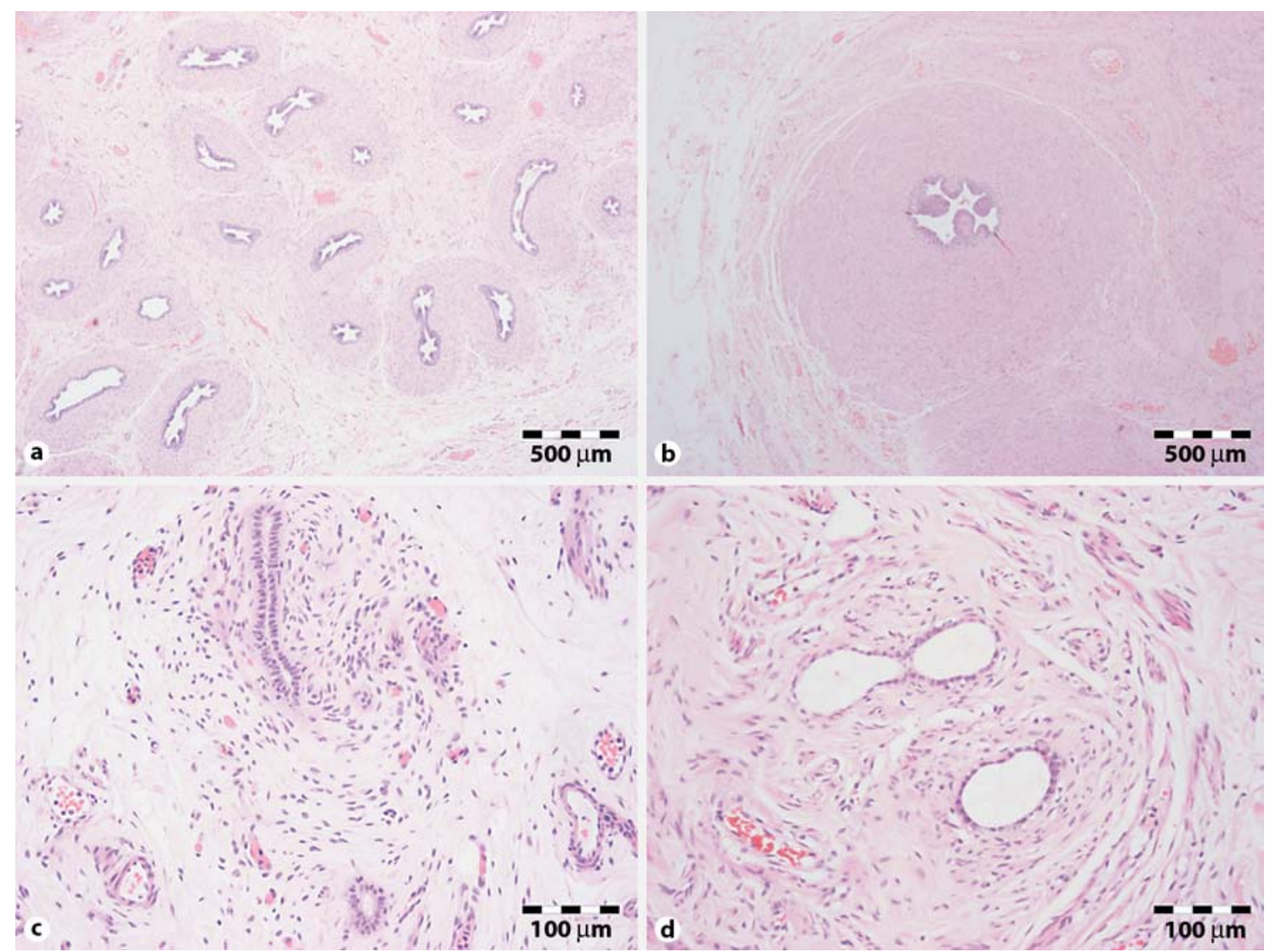

Fig. 5. WD derivatives in patients with CAIS. a, b Well-developed epididymis and vas deferens in a patient with mutation M780I, associated with residual activity in vitro [51]. c, d Wolffian remnants in patients with mutations R831X and deletion of base T2660 (causing a frameshift); both these mutations abolish AR activity in vitro.

Fig. 6. Schematic overview of the hypothesised mode of action of endocrine dispruptors that interfere with WD development. Phthalates are thought to reduce synthesis of T by L; SHBG production is also increased, perhaps secondary to low androgen levels [65]. Linuron is a competitive AR antagonist in vitro that is believed to inhibit AR signalling directly [61]. L = Leydig cells; SHBG = sex hormone binding globulin; $\mathrm{T}=$ testosterone.

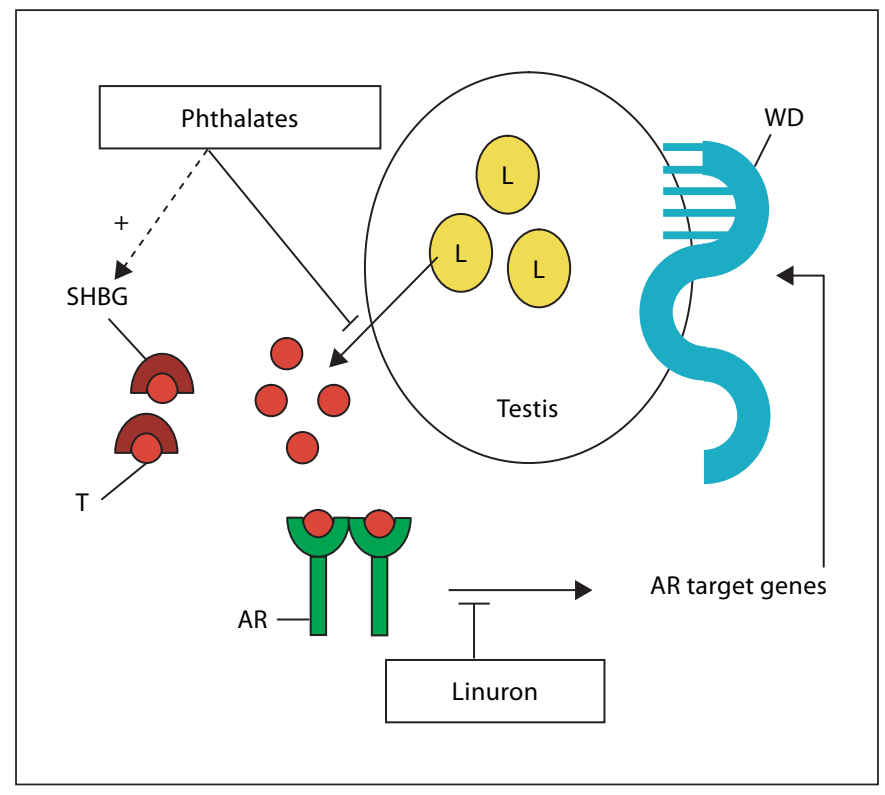


mice is in keeping with observations of hCG/LH-independent androgen synthesis in foetal Leydig cells in very early gestation $[18,59]$.

\section{$5 \alpha$-Reductase Deficiency}

In patients with $5 \alpha$-reductase deficiency testosterone is not efficiently converted to dihydrotestosterone, resulting in mild to severe undervirilisation of the external genitalia. However, WD development is normal, since this is dependent on testosterone, which is present at normal or high concentrations.

\section{Endocrine Disrupters and WD Development}

Evidence that a quartet of male reproductive tract disorders (cryptorchidism, hypospadias, impaired spermatogenesis and testis cancer) is increasing in prevalence is linked to disturbance of prenatal testicular development labelled the testicular dysgenesis syndrome [60]. It has been suggested that this syndrome may be the result of environmental chemicals acting as endocrine disrupters to alter the balance in androgen and estrogen dynamics (fig. 6). The evidence for this hypothesis is based mainly on nonhuman studies. Prenatal exposure of rat embryos to linuron, a herbicide and weak anti-androgen, results in several abnormalities of the $\mathrm{WD}$, including de- creased coiling and absence of parts of the epididymis. Genes that are up- or downregulated in the malformed WDs from rats exposed to linuron compared to controls, include those involved in Egf, Igf1, Bmp, Fgf and Notch signalling [61]. Similarly, in utero exposure to di(n-butyl) phthalate, a common plasticiser and solvent, causes a reduction in foetal testosterone levels by changes in gene expression of a number of enzymes and transport proteins involved in androgen synthesis and action [62]. The net result is malformation of the epididymis, vas deferens and seminal vesicles as well as abnormalities of the prostate gland and external genitalia. Studies in humans have shown significant correlations between levels of phthalate monoesters in breast milk and lowered free testosterone levels in the male offspring, with an increased LH:free testosterone ratio [63]. This indicates a reduction of the activity of Leydig cells characteristic of the early infant period. Furthermore, another study has reported a reduction in the anogenital index (a sensitive marker of androgen effect in utero) in infant boys in association with increased levels of phthalates in maternal urine samples collected during gestation [64]. Clearly, there are no data on whether the WD in humans is affected by exposure to phthalates, but these ubiquitous chemicals are only one group of a multitude of chemicals in the environment to which the developing foetus is potentially exposed.

\section{References}

1 Kobayashi A, Behringer RR: Developmental genetics of the female reproductive tract in mammals. Nat Rev Genet 2003;12:969980.

2 Capel B: The battle of the sexes. Mech Dev 2000;92:89-103.

- 3 Sainio K, Hellstedt P, Kreidberg JA, Saxén L, Sariola H: Differential regulation of two sets of mesonephric tubules by WT-1. Development 1997;124:1293-1299.

4 Hashimoto R: Development of the human Müllerian duct in the sexually undifferentiated stage. Anat Rec 2003;272A:514-519.

5 Didier E: Le canal de Wolff induit la formation de l'ostium müllérien: démonstration expérimentale chez l'embryon de poulet. J Embryol Exp Morphol 1971;25:115-129.

-6 Torres M, Gómez-Pardo E, Dressler GR, Gruss P: Pax-2 controls multiple steps of urogenital development. Development 1995; 121:4057-4065.

-7 Bouchard M, Souabni A, Mandler M, Neubüser A, Busslinger M: Nephric lineage specification by Pax 2 and Pax8. Genes Dev 2002; 16:2958-2970.
8 Kobayashi A, Behringer RR: Developmental genetics of the female reproductive tract in mammals. Nat Rev Genet 2003;4:969-980.

-9 Miyamoto N, Yoshida M, Kuratani S, Matsuo I, Aizawa S: Defects of urogenital development in mice lacking $E m \times 2$. Development 1997;124:1653-1664.

10 Mendelsohn C, Lohnes D, Decimo D, Lufkin T, LeMeur M, Chambon P, Mark M: Function of the retinoic acid receptors (RARs) during development (II). Multiple abnormalities at various stages of organogenesis in RAR double mutants. Development 1994; 120:2749-2771.

11 Hsieh-Li HM, Witte DP, Weinstein M, Branford W, Li H, Small K, Potter SS: Hoxa 11 structure, extensive antisense transcription, and function in male and female fertility. Development 1995;121:1373-1385.

12 Warot X, Fromental-Ramain C, Fraulob V, Chambon P, Dolle P: Gene dosage dependent effects of the Hoxa-13 and Hoxd-13 mutations on morphogenesis of the terminal parts of the digestive and urogenital tracts. Development 1997;124:4781-4791.
13 Podlasek CA, Seo RM, Clemens JQ, Ma L, Maas RL, Bushman W: Hoxa-10 deficient male mice exhibit abnormal development of the accessory sex organs. Dev Dyn 1999;214: $1-12$.

14 Bomgardner D, Hinton BT, Turner TT: 5' Hox genes and Meis 1, a Hox-DNA binding cofactor, are expressed in the adult mouse epididymis. Biol Reprod 2003;68:644-650.

15 Podlasek CA, Clemens JQ, Bushman W: HOXA-13 gene mutation results in abnormal seminal vesicle and prostate development. J Urol 1999; 161:1655-1661.

16 Benson GV, Lim H, Paria BC, Satokata I, Dey SK, Maas RL: Mechanisms of reduced fertility in Hoxa-10 mutant mice: uterine homeosis and loss of maternal Hoxa-10 expression. Development 1996;122:2687-2696.

17 Jost A: Problems of fetal endocrinology: the gonadal and hypophyseal hormones. Recent Prog Horm Res 1953;8:379-418.

18 Huhtaniemi I: Fetal testis - a very special endocrine organ. Eur J Endocrinol 1994;130: 25-31. 
19 Tong SYC, Hutson JM, Watts LM: Does testosterone diffuse down the Wolffian duct during sexual differentiation? J Urol 1996; 155:2057-2059.

20 Yeh S, Tsai M, Xu Q, Mu X, Lardy H, Huang K, Lin H, Yeh S, Altuwaijri S, Zhou X, Xing L, Boyce BF, Hung M, Zhang S, Gan L, Chang $\mathrm{C}$ : Generation and characterization of androgen receptor knockout (ARKO) mice: an in vivo model for the study of androgen functions in selective tissues. Proc Natl Acad Sci USA 2002;99:13498-13503.

-21 Bentvelsen FM, Brinkmann AO, van der Schoot $\mathrm{P}$, van der Linden JETM, van der Kwast TH, Boersma WJA, Schröder FH, Nijman JM: Developmental pattern and regulation by androgens of androgen receptor expression in the urogenital tract of the rat. Mol Cell Endocrinol 1995;113:245-253.

-22 Cunha GR, Young P: Inability of Tfm (testicular feminization) epithelial cells to express androgen-dependent seminal vesicle secretory proteins in chimeric tissue recombinants. Endocrinology 1991;128:32933298.

-23 Cunha GR, Reese BA, Sekkingstad M: Induction of nuclear androgen-binding sites in epithelium of the embryonic urinary bladder by mesenchyme of the urogenital sinus of embryonic mice. Endocrinology 1980;107: 1767-1770.

24 Higgins SJ, Young P, Cunha GR: Induction of functional cyto-differentiation in the epithelium of tissue recombinants. II. Instructive induction of Wolffian duct epithelia by neonatal seminal vesicle mesenchyme. Development 1989;106:235-250.

25 Cunha GR, Young P, Higgins SJ, Cooke PS: Neonatal seminal vesicle mesenchyme induces a new morphological and functional phenotype in the epithelia of adult ureter and ductus deferens. Development 1991;111: 145-158.

26 Gupta C, Singh M: Stimulation of epidermal growth factor gene expression during the fetal mouse reproductive tract differentiation: role of androgen and its receptor. Endocrinology 1996;137:705-711.

27 Gupta C: The role of epidermal growth factor receptor (EGFR) in male reproductive tract differentiation: stimulation of EGFR expression and inhibition of Wolffian duct differentiation with anti-EGFR antibody. Endocrinology 1996;137:905-910.

28 Gupta C, Siegel S, Ellis D: The role of EGF in testosterone-induced reproductive tract differentiation. Dev Biol 1991;146:106-116.

29 Gupta C, Chandorkar A, Nguyen AP: Activation of androgen receptor in epidermal growth factor modulation of fetal mouse sexual differentiation. Mol Cell Endocrinol 1996;123:89-95.
30 Gupta C: Modulation of androgen receptor (AR)-mediated transcriptional activity by EGF in the developing mouse reproductive tract primary cells. Mol Cell Endocrinol 1999;152:169-178.

31 Nguyen AP, Chandorkar A, Gupta C: The role of growth hormone in fetal mouse reproductive tract differentiation. Endocrinology 1996;137:3659-3666.

32 Baker J, Hardy MP, Zhou J, Bondy C, Lupu F, Bellvé AR, Efstratiadis A: Effects of an Igf1 gene null mutation on mouse reproduction. Mol Endocrinol 1996;10:903-918.

33 Chua SS, Ma Z, Gong L, Lin S, DeMayo FJ, Tsai SY: Ectopic expression of FGF-3 results in abnormal prostate and Wolffian duct development. Oncogene 2002;21:1899-1908.

34 Thomson AA: Role of androgens and fibroblast growth factors in prostatic development. Reproduction 2001;121:187-195.

35 Alarid ET, Rubin JS, Young P, Chedid M, Ron D, Aaronson SA, Cunha GR: Keratinocyte growth factor functions in epithelial induction during seminal vesicle development. Proc Natl Acad Sci USA 1994;91:1074-1078.

-36 Sanford LP, Ormsby I, Gittenberger-de Groot AC, Sariola H, Friedman R, Boivin GP, Cardell EL, Doetschman T: TGFß2 knockout mice have multiple developmental defects that are non-overlapping with other TGF $\beta$ knockout phenotypes. Development 1997;124:2659-2670.

37 Stenvers KL, Tursky ML, Harder KW, Kountouri N, Amatayakul-Chantler S, Grail D, Small C, Weinberg RA, Sizeland AM, Zhu $\mathrm{HJ}$ : Heart and liver defects and reduced transforming growth factor $\beta 2$ sensitivity in transforming growth factor $\beta$ type III receptor-deficient embryos. Mol Cell Biol 2003; 23:4371-4385.

38 Kireeva ML, Latinkíc BV, Kolesnikova TV, Chen CC, Yang GP, Abler AS, Lau LF: Cyr61 and Fisp12 are both ECM-associated signaling molecules: activities, metabolism, and localization during development. Exp Cell Res 1997;233:63-77.

39 Hannema SE, Print CG, Charnock-Jones DS, Coleman N, Hughes IA: Changes in gene expression during Wolffian duct development. Horm Res 2006;65:200-209.

40 Okamoto O, Fujiwara S, Abe M, Sato Y: Dermatopontin interacts with transforming growth factor $\beta$ and enhances its biological activity. Biochem J 1999;337:537-541.

-41 Mendive F, Laurent P, van Schoore G, Skarnes W, Pochet R, Vassart G: Defective postnatal development of the male reproductive tract in LGR4 knockout mice. Dev Biol 2006;290: 421-434.

42 Stuhrmann M, Dork T: CFTR gene mutations and male infertility. Andrologia 2000; 32:71-83.

-43 Jequier AM, Ansell ID, Bullimore NJ: Congenital absence of the vasa deferentia presenting with infertility. J Androl 1985;6:1519.
-44 McCallum TJ, Milunsky JM, Cunningham DL, Harris DH, Maher TA, Oates RD: Fertility in men with cystic fibrosis: an update on current surgical practices and outcomes. Chest 2000;118:1059-1062.

45 Tizzano EF, Silver MM, Chitayat D, Benichou JC, Buchwald M: Differential cellular expression of cystic fibrosis transmembrane regulator in human reproductive tissues. Clues for the infertility in patients with cystic fibrosis. Am J Pathol 1994;144:906-914.

46 Reynaert I, van der Schueren B, Degeest G, Manin M, Cuppens H, Scholte B, Cassiman $\mathrm{J}$ : Morphological changes in the vas deferens and expression of the cystic fibrosis transmembrane conductance regulator (CFTR) in control, $\Delta$ F508 and knock-out $c f t r$ mice during postnatal life. Mol Reprod Dev 2000;55: 125-135.

47 Morris JM: The syndrome of testicular feminization in male pseudohermaphrodites. Am J Obstet Gynecol 1953;65:1192-1211.

48 Quigley CA, De Bellis A, Marschke KB, ElAwady MK, Wilson EM, French FS: Androgen receptor defects: historical, clinical, and molecular perspectives. Endocr Rev 1995;16: 271-321.

49 Bale PM, Howard NJ, Wright JE: Male pseudohermaphroditism in XY children with female phenotype. Pediatr Pathol 1992;12:2949.

50 Boehmer ALM, Brüggenwirth H, van Assendelft C, Otten BJ, Verleun-Mooijman MCT, Niermeijer MF, Brunner HG, Rouwé CW, Waelkens JJ, Oostdijk W, Kleijer WJ, van der Kwast TH, de Vroede MA, Drop SLS: Genotype versus phenotype in families with androgen insensitivity syndrome. J Clin Endocrinol Metab 2001;86:4151-4160.

-51 Hannema SE, Scott IS, Hodapp J, Martin H, Coleman N, Schwabe JW, Hughes IA: Residual activity of mutant androgen receptors explains Wolffian duct development in the complete androgen insensitivity syndrome. J Clin Endocrinol Metab 2004;89:58155822.

52 Hannema SE, Scott IS, Rajpert-de Meyts E, Skakkebaek NE, Coleman N, Hughes IA: Testicular development in the complete androgen insensitivity syndrome. J Pathol 2006;208:518-527.

53 Andersson S, Geissler WM, Wu L, Davis DL, Grumbach MM, New MI, Schwarz HP, Blethen SL, Mendonca BB, Bloise W, Witchel SF, Cutler Jr GB, Griffin JE, Wilson JD, Russell DW: Molecular genetics and pathophysiology of $17 \beta$-hydroxysteroid dehydrogenase 3 deficiency. J Clin Endocrinol Metab 1996;81:130-136.

54 Chen F, Knecht K, Leu C, Rutledge SJ, Scafonas A, Gambone C, Vogel R, Zhang H, Kasparcova V, Bai C, Harada S, Schmidt A, Reszka A, Freedman L: Partial agonist/antagonist properties of androstenedione and 4-androsten-3 $\beta, 17 \beta$-diol. J Steroid Biochem Mol Biol 2004;91:247-257. 
-55 Berthezène F, Forest MG, Grimaud JA, Claustrat B, Mornex R: Leydig-cell agenesis. A cause of male pseudohermaphroditism. N Engl J Med 1976;295:969-972.

-56 Themmen APN, Huhtaniemi IT: Mutations of gonadotropins and gonadotropin receptors: elucidating the physiology and pathophysiology of pituitary-gonadal function. Endocr Rev 2000;21:551-583.

-57 Lei ZM, Mishra S, Zou W, Xu B, Foltz M, Li $\mathrm{X}$, Rao CV: Targeted disruption of luteinizing hormone/human chorionic gonadotropin receptor gene. Mol Endocrinol 2001;15: 184-200.

58 Lei ZM, Zou W, Mishra S, Li X, Rao ChV: Epididymal phenotype in luteinizing hormone receptor knockout animals and its response to testosterone replacement therapy. Biol Reprod 2003;68:888-895.
Lejeune H, Habert R, Saez JM: Origin, proliferation and differentiation of Leydig cells. J Mol Endocrinol 1998;20:1-25.

60 Bay K, Asklund C, Skakkebaek NE, Andersson A: Testicular dysgenesis syndrome: possible role of endocrine disrupters. Best Pract Res Clin Endocrinol Metab 2006;20:77-90.

61 Turner KJ, McIntyre BS, Phillips SL, Barlow NJ, Bowman CJ, Foster PMD: Altered gene expression during rat Wolffian duct development in response to in utero exposure to the antiandrogen linuron. Toxicol Sci 2003; 74:114-128.

62 Foster PMD: Disruption of reproductive development in male rat offspring following in utero exposure to phthalate esters. Int J Androl 2006;29:140-147.
63 Main KM, Mortensen GK, Kaleva MM, Boisen KA, Damgaard IN, Chellakooty M, Schmidt IM, Suomi A, Virtanen HE, Petersen JH, Andersson A, Toppari J, Skakkebaek NE: Human breast milk contamination with phthalates and alterations of endogenous reproductive hormones in infants three months of age. Environ Health Perspect 2006;114:270-276.

64 Swan SH, Main KM, Liu F, Stewart SL, Kruse RL, Calafat AM, Mao CS, Redmon JB, Ternand CL, Sullivan S, Teague JL; the study of future families research team: decrease in anogenital distance among male infants with prenatal phthalate exposure. Environ Health Perspect 2005;113:1056-1061.

65 Lottrup G, Andersson A, Leffers H, Mortensen GK, Toppari J, Skakkebaek NE, Main KM: Possible impact of phthalates on infant reproductive health. Int J Androl 2006;29:172-180. 